\title{
Red algal exotics on North Sea coasts
}

\author{
Christine A. Maggs ${ }^{1}$ \& Herre Stegenga ${ }^{2}$ \\ ${ }^{1}$ School of Biology and Biochemistry, Queen's University of Belfast, Belfast BT9 $7 B L$, \\ $U K$ \\ ${ }^{2}$ Rijksherbarium, Van Steenis Gebouw, Einsteinweg 2, P.O. Box 9514, 2300 RA Leiden, \\ The Netherlands
}

\begin{abstract}
A total of ten red seaweed species are recognized as introduced into the North Sea from other parts of the world. These are Asparagopsis armata and Bonnemaisonia hamifera (Bonnemaisoniales), Grateloupia doryphora (Halymeniales), Antithamnionella spirographidis, Antithamnionella ternifolia, Anotrichium furcellatum, Dasya baillouviana, ?Dasysiphonia sp., Polysiphonia harveyi and Polysiphonia senticulosa (Ceramiales). The oldest of these is $B$. hamifera, introduced prior to 1890, while the most recent, ?Dasysiphonia sp., was first found in 1994 and still requires taxonomic investigation. A variety of distribution patterns is seen, with geographical ranges varying from general within the North Sea to very restricted. The diversity of introduced red algae on eastern coasts of the North Sea is much greater than in the west. The most likely explanation for this pattern is that French coasts were the initial site of introduction for many of the seaweeds, which were then distributed northwards by the residual surface currents. Their increasing success in the Netherlands has probably been promoted by the drastically changed local hydrodynamic conditions which have also permitted the recent introduction of many native European species. Of the biological features of species that may favour their success as introductions, clonal vegetative propagation, often with specialized propagules or fragmentation mechanisms, is almost ubiquitous. Low-temperature tolerances can be inferred, but data are sparse. Many of the alien red algae in the North Sea contain anti-grazing compounds such as bromophenols, which may contribute to their invasive potential by deterring grazing sufficiently to permit establishment of an inoculum.
\end{abstract}

\section{INTRODUCTION}

The first introductions of exotic seaweeds into northern Europe were recognized in the late nineteenth and early twentieth centuries (Farnham, 1980). The subsequent spread of these seaweeds was followed keenly by phycologists in the 1930s and 1940s. During the 1970 s there was a resurgence of interest in introduced algae, prompted by the recognition of several new aliens (Farnham, 1980), which culminated in determined attempts to eradicate the fucoid brown alga Sargassum muticum from the south coast of England. The failure to eliminate or even slow the spread of $S$. muticum probably contributed to a decline in the attention paid to alien seaweeds. Over the last few years there has been a renewal of interest in marine introductions (Sinderman et al., 1992; Boudouresque et al., 1994; Ribera \& Boudouresque, 1995). Ballast water has been the main focus, however, and as it contains very few macroalgal propagules the marine macroalgae have often been ignored (Carlton \& Geller, 1993). Now, however, compre- 


\section{ALIEN RED ALGAE IN THE BRITISH ISLES TOTAL $=10$}

Asparagopsis armata Bonnemaisonia hamifera Grateloupia doryphora Grateloupia luxurians Pikea californica Agardhiella subulata Anotrichium furcellatum Antithamnionella spirographidis Antithamnionella temifolia Polysiphonia harveyi

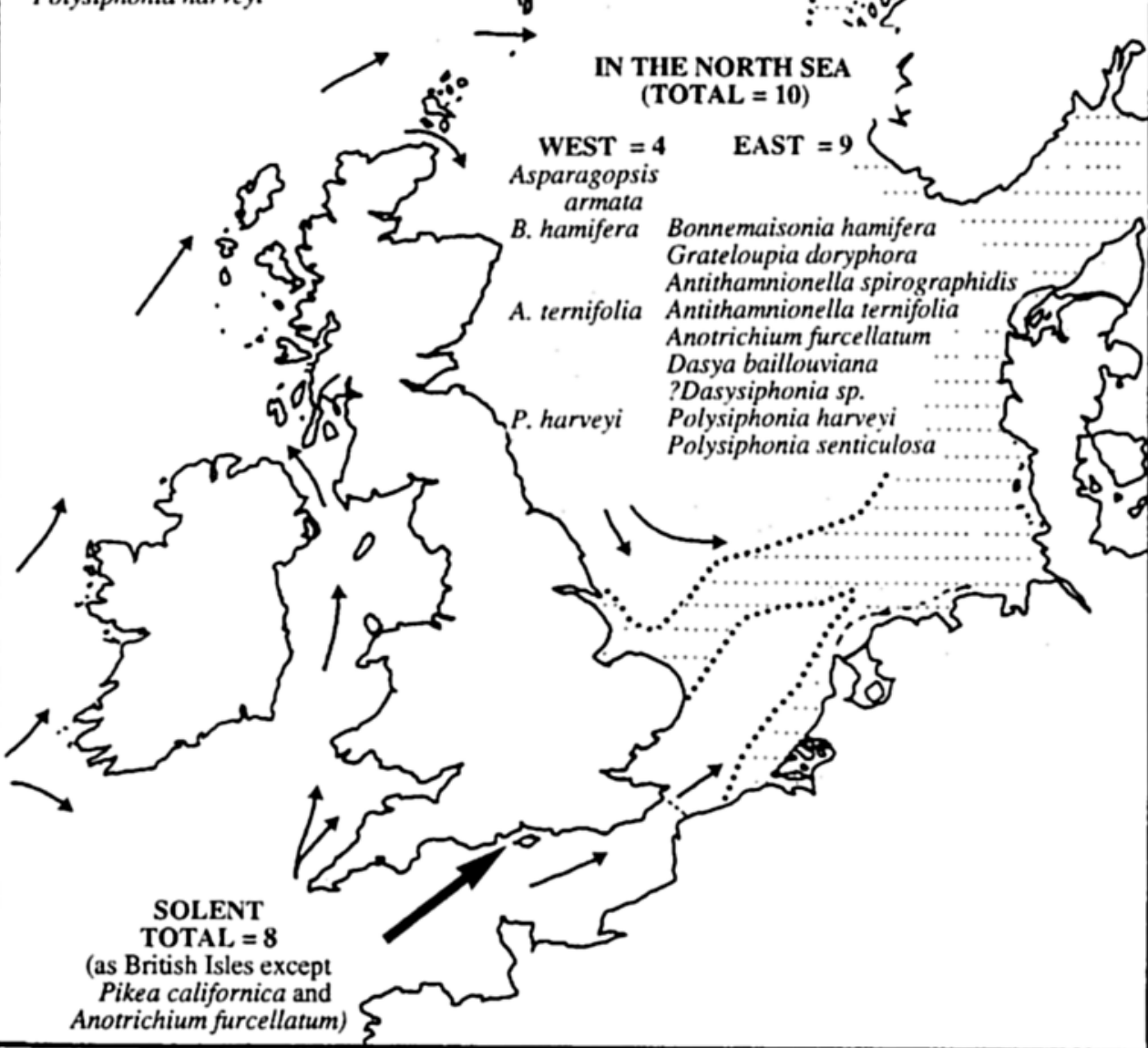

Fig. 1. Map of north-west Europe showing oceanographic features and broad-scale distribution of introduced red algae. British Isles and Solent lists were derived from Farnham (1980) and Maggs \& Hommersand (1993). Designated boundaries of the North Sea are indicated by dashed lines. Arrows indicate residual currents (from Lee \& Ramster, 1981). Dotted lines are $5^{\circ} \mathrm{C}$ February isotherms; surface temperatures in shaded area are below $5^{\circ} \mathrm{C}$ 
hensive lists of introduced seaweeds have been produced for European waters. The Joint Nature Conservation Committee has published a directory of non-native marine organisms in British waters (Eno et al., 1997) and a comprehensive European list is currently being revised (S. Gollasch, personal communication).

This paper will be confined to red macroalgae believed to have been introduced into the North Sea by human activities. The North Sea is here regarded as extending from the Dover-Calais constriction of the English Channel northwards to a line between the Shetland Islands and Bergen, Norway (Fig. 1), and eastwards to its junction with the Baltic Sea at the Skagerrak-Kattegat line. In order to put the total numbers of invading red algae in the North Sea into context, they are compared with those in another well-studied and ecologically diverse geographical region, the British Isles (Fig. 1). Although some species are present in only one area or another, the total numbers in both regions are similar. However, a comparison with the Solent region of England, which has long been regarded as a 'hotspot' for introductions (Farnham, 1980), shows that nearly as many species of alien red algae are found in the Solent as in the whole North Sea.

Each of the introduced red algae found in the North Sea will now be considered separately, in taxonomic order. For each species, the reasons for recognizing it as introduced will be discussed briefly, with some mention of the vector of introduction if known, and we summarize its geographical distribution and habitat in the North Sea. We will then concentrate on the biological features of each species that may have favoured its success as an invader. The type of data we cover include morphological and biochemical features, physiological results and life-history data from culture studies where available; we will also refer to relevant, mostly unpublished, molecular data. Although Porphyra yezoensis Ueda was reported from Helgoland (Kornmann, 1986), we exclude it here on the basis of a comparison of nucleotide sequence data (of the Rubisco large subunit-small subunit spacer region) with that of authentic material from Japan (J. Brodie, personal communication). Mastocarpus stellatus (Stackhouse) Guiry has been introduced to Helgoland by scientific activity (Kornmann \& Sahling, 1994), but it cannot be regarded as an exotic in the North Sea, being native to many North Sea coasts. Finally, we will summarize the information for different species and draw conclusions concerning features of red algae that may be important in ensuring their success as invaders of the North Sea.

\section{RESULTS AND DISCUSSION}

\section{Asparagopsis armata Harvey (Bonnemaisoniaceae, Bonnemaisoniales)}

Western Australia is the type locality of both Asparagopsis armata Harvey and its morphologically dissimilar tetrasporangial Falkenbergia phase. A. armata is very distinctive, the only red seaweed to form barbed harpoon-like spines. The first Atlantic population appeared in 1925 at Guéthary in the Bay of Biscay (Irvine et al., 1975), and it was discovered almost simultaneously at two Mediterranean localities. The Falkenbergia phase was noticed first in the British Isles (at Galway) in 1939; gametophytes were found at Galway 2 years later. The Falkenbergia phase is now widespread in the 
Table 1. North Sea distribution of exotic red algae, with totals recorded in each area

\begin{tabular}{|c|c|c|c|c|c|c|c|}
\hline Species & $\begin{array}{l}\text { Shetland } \\
\text { Orkney }\end{array}$ & $\begin{array}{l}\text { E Scot- } \\
\text { land } \\
N E \\
\text { England }\end{array}$ & $\begin{array}{c}\text { E \& SE } \\
\text { England }\end{array}$ & $\begin{array}{l}\text { S Nor- } \\
\text { way } \\
\text { W Swe- } \\
\text { den }\end{array}$ & $\begin{array}{l}\text { Den- } \\
\text { mark } \\
\text { Ger- } \\
\text { many }\end{array}$ & $\begin{array}{l}\text { Nether- } \\
\text { lands }\end{array}$ & $\begin{array}{l}\text { Belgium } \\
\text { NE France }\end{array}$ \\
\hline Asparagopsis armata & + & - & - & - & - & $\begin{array}{l}- \\
\text { (Drift } \\
\text { only) }\end{array}$ & - \\
\hline Bonnemaisonia hamifera & + & + & + & + & + & $\begin{array}{l}- \\
\text { (Drift } \\
\text { only) }\end{array}$ & + \\
\hline Grateloupia doryphora & - & - & - & - & - & + & - \\
\hline $\begin{array}{l}\text { Antithamnionella } \\
\text { spirographidis }\end{array}$ & - & - & - & - & - & + & + \\
\hline Antithamnionella ternifolia & - & + & - & - & - & + & + \\
\hline Anotrichium furcellatum & - & - & - & - & - & + & - \\
\hline Dusya baillouviana & - & - & - & + & + & + & - \\
\hline ?Dasysiphonia sp. & - & - & - & - & - & + & - \\
\hline Polysiphonia harveyi & - & + & + & + & + & + & + \\
\hline Polysiphonia senticulosa & - & - & - & - & - & + & - \\
\hline Total & 2 & 3 & 2 & 3 & 3 & 8 & 4 \\
\hline
\end{tabular}

British Isles, although rare on east coasts, while the gametophyte appears to be confined to southern and south-western coasts (Farnham, 1980).

The gametophytic and tetrasporangial phases of $A$. armata are believed to have been introduced to Europe, possibly separately, from Australia. A second species, A. taxiformis (Delile) Trevisan, is widespread in the tropics and in the Mediterranean; its key morphological character is the absence of barbed spines. The origins of $A$. armata in northern Europe have been investigated using 24 Falkenbergia strains from Atlantic and Mediterranean Europe, the Caribbean, and the North and South Pacific including Australia (Ní Chualáin, 1997; F. Ni Chualáin, C. Maggs \& M. Guiry, unpublished data). Upper and lower temperature limits for growth and reproduction were determined and restriction analysis of chloroplast DNA was carried out. All seven isolates from Atlantic Europe were identified as $A$. armata because they were identical to a strain of $A$. armata collected at the type locality. They survived temperatures of $5-25^{\circ} \mathrm{C}$, and grew at $9{ }^{\circ} \mathrm{C}$ to $21(-23)^{\circ} \mathrm{C}$. No restriction site mutations were found among these isolates, which appeared to be genetically uniform at this level of resolution.

In the North Sea, $A$. armata (Falkenbergia phase only) is apparently known only from Orkney and Shetland (Table 1; Irvine et al., 1975). In Orkney it was found at two localities, growing epiphytically in intertidal pools, and it was also collected twice in Shetland (once intertidally, once subtidally). In the Netherlands only drift material of both phases has been seen, presumably originating in northern France as it does not occur in Belgium. The temperature tolerances of Falkenbergia show unequivocally that $A$. armata is the only Asparagopsis species that can colonize the coasts of the British Isles; isolates of A. taxiformis sensu lato have lower survival limits of (9) $11-17^{\circ} \mathrm{C}$. The very 
restricted distribution of Falkenbergia in the North Sea is explained by its intolerance of winter temperatures below $5^{\circ} \mathrm{C}$, which are experienced throughout the southern and eastern North Sea (ICES, 1962).

Several key features of A. armata seem to be associated with its great success as an invader in the British Isles, where the tetrasporophyte forms monospecific stands in suitable habitats.

1. It has a high capacity for clonal reproduction. Both phases reproduce vegetatively (Dixon, 1965); the Falkenbergia phase spreads easily as floating balls while the gametophyte hooks onto floating material. Rapid clonal spread in Europe is reflected in the genetic identity of all European Atlantic populations.

2. It survives lower temperatures than other Asparagopsis species, although not low enough to permit it to colonize most of the North Sea.

3. Asparagopsis forms large amounts of halogens and organic halogen-containing ketones (Fenical, 1975), which are closely related to the tear gas component monobromoacetone and toxic to bacteria, fungi and humans (despite this A. taxiformis is eaten in Hawaii!). Asparagopsis species including the Falkenbergia phase of $A$. armata also produce the noxious compound bromoform (Norris \& Fenical, 1982). These halogenated compounds are effective anti-grazing agents, and $A$. taxiformis is not eaten by fish or urchins (Norris \& Fenical, 1982).

\section{Bonnemaisonia hamifera Hariot (Bonnemaisoniaceae, Bonnemaisoniales)}

The tetrasporophytic (Trailliella) and gametophytic phases of Bonnemaisonia hamifera were first found in Europe (southern England) in 1890 and 1893 respectively (Farnham, 1980). Both phases are easily recognizable, the gametophyte by its hooks and the Trailliella phase by the presence of gland cells in a distinctive alternate arrangement. The Trailliella phase has spread northwards to Iceland and southwards to the Canaries, and from Labrador to Virginia (Breeman et al., 1988). Bonnemaisonia hamifera is thought to have been introduced from Japan; plastid DNA restriction fragment length polymorphisms (C. Maggs \& M. Guiry, unpublished data) are identical in European and Japanese isolates. Today, it is so widespread and abundant in Europe that it can be regarded as fully established, with no possibility of eradication.

The Trailliella phase occurs throughout the North Sea, growing subtidally in Scotland and eastern England, and from northern Norway to France, although it is known in the Netherlands only as drift. The gametophytic phase is absent from northern Norway but occurs southwards from southern Norway (Breeman et al., 1988). The differential distribution of the gametophytic and sporophytic phases of $B$. hamifera results from complex interactive responses to temperature and daylength in this species (Lüning, 1980; Breeman et al., 1988). Reproduction in Trailliella requires a combination of high temperature and short days, resulting in an autumn "reproductive window" before the temperature becomes too low (Lüning, 1980). In northern Norway, the window is closed. Maturation of gametophytes is also temperature-sensitive. B. hamifera is protandrous, and in the northwest Atlantic males finish reproducing before females are fertile, so the life history is not completed there (Breeman et al., 1988); sporophytes survive by asexual propagation. The species is much better adapted to conditions in Japan than 
those in the North Atlantic, consistent with other evidence that it has been introduced from Japan.

The features of $B$. hamifera that suit it to life as an invader of the North Sea are similar to those already considered for the related Asparagopsis armata. Its wider distribution and Japanese rather than Australian origins are correlated with greater physiological tolerances, however. It is more eurythermal than $A$, armata, surviving $0-28^{\circ} \mathrm{C}$ (Lüning, 1984): of 23 Helgoland red algae tested by Lüning, only two tolerated higher temperatures. Both gametophytes and sporophytes can grow at $0^{\circ} \mathrm{C}$, but gametophytes have a distinct growth optimum of $15^{\circ} \mathrm{C}$ whereas Trailliella grows well at $25^{\circ} \mathrm{C}$ (Breeman et al., 1988), consistent with summer temperatures of $25^{\circ} \mathrm{C}$ at Shimoda, central Japan. Trailliella thrives under a wide range of environmental conditions in the British Isles, including those associated with very muddy and sheltered, almost anoxic habitats, where it forms beds up to $100 \mathrm{~cm}$ thick (Connor et al., 1997). Trailliella is particularly abundant in impoverished communities such as those heavily grazed by sea urchins. The gland cells of Trailliella accumulate halogens (bromine is concentrated 30 -fold, iodine 3 -fold, relative to the ordinary cells), as shown by X-ray fluorescence electron microprobe spectroscopy (Wolk, 1968). Like A. armata, both life-history phases spread rapidly by vegetative reproduction. The gametophyte attaches itself by its hooks to other material, such as Zostera fragments, and it is frequently found among drift material.

\section{Grateloupia doryphora (Montagne) Howe (Halymeniaceae, Halymeniales)}

A large foliose species of Grateloupia discovered in 1969 in the Solent was attributed by Farnham (1980) to G. doryphora on the basis of its morphological similarity to this Pacific alga and presumed to be an introduction. Marginal expansion in the Solent was slow initially, and after a decade it had colonized only about $20 \mathrm{~km}$ in both directions from the original site. It took more than 20 years to reach the Isle of Wight, $8 \mathrm{~km}$ offshore (Farnham, 1997). However, in the meantime (by 1984) it had spread to Milford Haven, Wales, growing near an oyster farm where it was still present in 1996. It was also found in the Mediterranean at Messina, Italy (de Masi \& Gargiulo, 1982). Rapid expansion is now taking place in the eastern North Atlantic. Grateloupia doryphora was found in the Channel Islands in 1995 (Farnham, 1997), and is now well established on the coasts of Brittany (Cabioch et al., 1997) and northern Spain (Farnham, 1997).

The only known North Sea site for this species is in former oyster ponds near Yerseke, in the tidal Oosterschelde, the Netherlands, where single thalli were found twice, on 18 August 1993 (tetrasporangial: Stegenga \& Otten, 1997) and 15 November 1996 (cystocarpic: specimens in Leiden herbarium, L, collected by H. Stegenga).

Most of the newly discovered European populations are in the vicinity of shellfish farms, suggesting that this species has been transported with commercial molluscs. $G$. doryphora has recently appeared at Rhode Island, USA (Villalard-Bohnsack \& Harlin, 1997), but the vector involved is unknown.

\section{Antithamnionella spirographidis Schiffner (Ceramiaceae, Ceramiales)}

The earliest known British collection of Antithamnionella spirographidis was made in 1906 at Plymouth, but it was first described in 1911 from the Mediterranean (Maggs 
\& Hommersand, 1993). Lindstrom \& Gabrielson (1989) placed several North Pacific species in synonymy with $A$. spirographidis, and suggested that the species is of North Pacific origin. Culture studies support this conclusion, as Japanese, Californian and European isolates all interbreed freely (Maggs, unpublished data). It appears to have been introduced to Australia subsequently by shipping. A. spirographidis is small and inconspicuous, and confusion with A. ternifolia (see L'Hardy-Halos, 1986) obscured its initial spread. In southern England, it is particularly common in yacht marinas, and marginal dispersal in Europe probably involves small boats.

In the North Sea, A. spirographidis is known only in the Netherlands, where the first record is from 31 July 1974, in an oyster pond near Yerseke (collected by H. Stegenga, in L), and Belgium (Ostend in 1992: Coppejans, 1995). From 1993 onwards it has become rather common in the Netherlands in the tidal Oosterschelde, with a few collections from the stagnant saline Grevelingen. Plants occur year-round but are most abundant during the second half of the year. Tetrasporangia are formed throughout the year, and gametangia in May to November. Temperature tolerances of this species are unknown, but its presence in the Netherlands suggests that it could colonize suitable habitats in most of the North Sea.

Both introduced Antithamnionella species, A. spirographidis and A. ternifolia, have gland cells (Maggs \& Hommersand, 1993). Gland cells of antithamnioid algae contain large amounts of halogens such as the brominated compound eosine and other bromophenols (Fenical, 1975), and although these algae have not been subjected to grazing tests, it can be assumed that, as in the Bonnemaisoniaceae, they are grazing deterrents.

\section{Antithamnionella ternifolia (J. D. Hooker \& Harvey) Lyle (Ceramiaceae, Ceramiales)}

The first European record of Antithamnionella ternifolia was from northern France in 1910; it was found in the Channel Islands in 1921, was common in south Devon by 1926-1929, and was then reported from Ireland and the Isle of Man and later from western Scotland (Maggs \& Hommersand, 1993). When Lyle (1922) described her collections as a new species, $A$. sarniensis, she noted that the only similar plants were from the southern hemisphere, and assumed that the European population was introduced. The origins of this introduction are still unknown - the situation is complex as there are a number of morphologically similar and probably fairly closely related species in various parts of the world. Magne (1991) reported it as an introduction to Australia. L'HardyHalos (1986) found that the length and diameter of axial cells of tetraspore progeny from France vary. Some plants are short and stocky while others are more slender. This feature was genetically controlled - potential evidence of interspecific hybridization during the evolutionary history of this species.

In the North Sea, A. ternifolia is known from the SE coast of Scotland (St Abbs), where it was common on sublittoral bedrock at 4-14 $\mathrm{m}$ (Hiscock, 1984), and as single records from the Netherlands (specimen in L collected by Den Hartog, 21 October 1951, near Yerseke) and Belgium (Coppejans, 1995).

This species is common in the British Isles, spreading clonally by vegetative reproduction. It grows particularly well on artificial substrata such as ropes and marina pon- 
toons, facilitating its spread. Tetrasporangia are formed in the autumn, but released tetraspores fail to germinate or grow into deformed gametophytes. French isolates, by contrast, can undergo normal sexual reproduction although they also recycle tetrasporophytes apomictically (L'Hardy-Halos, 1986).

\section{Anotrichium furcellatum (J. Agardh) Baldock (Ceramiaceae, Ceramiales)}

Anotrichium furcellatum is believed to have been introduced from the Mediterranean to northern France prior to 1922 but the alga now present in the Mediterranean may not be identical to that originally found by J. Agardh (Feldmann-Mazoyer \& Meslin, 1939). Modern Mediterranean populations resemble Monospora tenuis Okamura from the Pacific, so they might have been derived from the introduction of a (possibly conspecific) Pacific form into the range of the original Mediterranean alga (FeldmannMazoyer \& Meslin, 1939). In the North Sea, A. furcellatum is known only from the Netherlands (Stegenga \& Mol, 1983). Material in L (six sheets in all) is from only two localities, Yerseke oyster ponds (five collections) and Sas van Goes (one collection), and was usually found in the form of free-floating "pompons". All collections were made in the period 1968-1977 (first record 2 October 1968 at Yerseke), during the summer (JulyOctober), with the only tetrasporangial sample obtained in August. This species has not been found in the Netherlands in recent years despite a rather intensive search at the original locations. In southern England, where the first collections were made in 1976 , A. furcellatum seems to be spreading. It rarely forms tetrasporangia but reproduces vigorously by secondary attachment and fragmentation (Feldmann-Mazoyer \& Meslin, 1939).

\section{Dasya baillouviana (S.G. Gmelin) Montagne (Dasyaceae, Ceramiales)}

Dasya baillouviana is widely distributed in the Mediterranean, westwards to Cadiz, and on the Atlantic coast of North America, from Nova Scotia to the Caribbean (Den Hartog, 1964; Dixon \& Irvine, 1970; Richardson, 1981); it appears to be native to both of these areas. In the North Sea attached specimens were first collected on 6 August 1950, in the "Kanaal door Zuid-Beveland" in SW Netherlands (Den Hartog, 1964, as Dasya pedicellata). The origin of this population is unknown, but Den Hartog (1964) noted that it was found only a few kilometers from oyster ponds. Dasya baillouviana is a very conspicuous species, growing to $175 \mathrm{~cm}$ in height, and is easily recognizable by its dense coat of pigmented hair-like monosiphonous filaments; soon (1953) it was noted on the west coast of Sweden and was present by 1961 in Denmark (Den Hartog, 1964) and 1969 in Norway. It now occurs quite widely in Denmark (Nielsen \& Kristiansen, 1994). In the Netherlands, $D$. baillouviana was collected regularly for several years after its initial discovery, but only at the original site and at "Gat van Ouwerkerk", another stagnant saline or brackish locality. The population in the Kanaal door Zuid-Beveland has persisted even though this canal was exposed to a tidal regime in 1994. Recently (since 1993), it has expanded its distribution, becoming established in the Veerse Meer (stagnant and brackish), Grevelingen (saline and stagnant) and, less abundantly, in the tidal Oosterschelde (near Yerseke). 
In the Netherlands Dasya baillouviana is a summer annual, occurring in July to October (to December). Both tetrasporophytes and gametophytes reproduce in July to October. The phenology of $D$. baillouviana in Nova Scotia, where this species is restricted to warm embayments, is very similar to that in the Netherlands. Large vegetative and reproductive thalli appear in August (when the temperature is ca. $25^{\circ} \mathrm{C}$ ) and survive until November when the temperature drops to $5^{\circ} \mathrm{C}$; only juveniles are present in July and December (Novaczek et al., 1987). By contrast, in North Carolina macroscopic thalli occur in winter and spring, February to May, reproducing in April and May (Richardson, 1981).

The most significant biological features accounting for the success of this species on eastern North Sea coasts are (1) its physiological tolerances, particularly those of the specialized perennating pad-like holdfasts, and (2) its ability to propagate vegetatively from fragments as small as single monosiphonous laterals.

In Europe $D$. baillouviana is euryhaline, being able to grow throughout a salinity range of 10-30 psu, and it can also tolerate pollution and high concentrations of hydrogen sulphide (Den Hartog, 1964). A culture from Nova Scotia was highly eurythermal (Novaczek et al., 1987). Mature thalli were clearly warm-temperate in their temperature optima, growing and reproducing at $15-28^{\circ} \mathrm{C}$, and surviving $10-31^{\circ} \mathrm{C}$. However, specialized perennating pads composed of starch-filled cells survived at $0{ }^{\circ} \mathrm{C}$ for 4 months and tolerated all temperatures up to $34^{\circ} \mathrm{C}$, the widest temperature range of the four Nova Scotian species tested. Tetrasporophytes grew rapidly and matured in only 6 weeks at $20^{\circ} \mathrm{C}$.

After reproduction has finished, the monosiphonous filaments that clothe the thalli are shed as filaments or single cells and act as propagules, giving rise to numerous new individuals (Novaczek et al., 1987). These propagules can develop into perennating pads, which also form directly on the thallus from attached filaments. In Nova Scotia, and presumably the Netherlands also, $D$. baillouviana overwinters in the form of these pads, while in North Carolina it persists during the summer, when temperatures can exceed $30^{\circ} \mathrm{C}$, as perennating discs which are resistant to graizing by sea urchins and fish (Richardson, 1981). Probably the most enigmatic aspect of the distribution of $D$. baillouviana in Europe, in view of its physiological tolerances and rapid reproduction, is why it has failed to colonize the east coast of England. The answer may lie in its reported intolerance of wave action (Den Hartog, 1964). On North American coasts, in the Mediterranean, and in western Europe, it appears to be restricted to wave-protected areas (sometimes with fairly strong tidal currents). Although sheltered embayments are generally absent from south-east England, the creation of new yacht marinas during the last decade could provide this species with a favourable habitat there. However, residual currents along the east coast of Britain flow southwards (Fig. 1) so these coasts may not receive drift material.

\section{Dasysiphonia sp. (Dasyaceae, Ceramiales)}

Dasysiphonia sp. is a large red alga (up to $30 \mathrm{~cm}$ high), first recorded in Europe on 28 June 1994, in former oyster ponds near Yerseke, The Netherlands (Stegenga, 1997) and in May 1995 was collected twice, independently, in the intertidal zone near the 
marine station at Roscoff, Brittany. An apparently identical red alga corresponding to this species is now rather common on the Galician coast, especially "in areas strongly influenced by human activities (i.e. mariculture)" (J. Cremades, personal commununication), and may have been introduced there as early as 1990. Its generic affinities are uncertain: the formation of the four pericentral cells in an opposite/transverse pattern appears to be unique within the family Dasyaceae. In NE Asia, from where this alga has presumably been introduced, this species has often mistakenly been identified as Heterosiphonia japonica Yendo (H. Stegenga, unpublished data; see de Jong et al., 1998).

It is now a common, sometimes abundant, species in most of the tidal Oosterschelde and occasionally in the stagnant Lake Grevelingen. Thalli occur throughout the year if the winter is mild. Only tetrasporophytes have been found to date, bearing stichidia in June to November. The initial introduction may have been into France, perhaps, like many other invading algae, with oysters. A factor in its success may be that, like Dasya baillouviana, this species regenerates easily from small fragments. As tetrasporangia are the only reproductive structures observed to date, it seems likely that this alga has an apomictic life history similar to that of many other Dasyaceae (Maggs, 1998).

\section{Polysiphonia harveyi Bailey (Rhodomelaceae, Ceramiales)}

Polysiphonia harveyi was described from Connecticut in 1848 and occupies the east coast of North America from Newfoundland to South Carolina. Recently, it was reported by Maggs \& Hommersand $(1990,1993)$ to be widespread and abundant in the British Isles. In Europe it can be identified readily by the key feature of the position of chloroplasts. They are only on radial walls of the periaxial cells, so that the cells appear transparent, whereas in other European members of the genus chloroplasts also lie against the outer walls. In the Pacific, by contrast, there appears to be a group of species with this character (Yoon, 1986). Its systematic and nomenclatural position is extremely problematic. This plastid feature was later reported for a Polysiphonia species described from Brittany in 1867, $P$. insidiosa, which is believed to be conspecific with $P$. harveyi. In Japan and Korea, $P$. harveyi-like algae, known as $P$. japonica Harvey and many other synonyms, are common and widespread. Northwest European populations may represent the last step in a cascade of introductions that started in the North Pacific. Specimens collected at Weymouth, Dorset, by A. D. Cotton in 1908 (in the Natural History Museum herbarium, BM) represent the first known British material of $P$. harveyi. Its eastern Atlantic distribution appears to be enlarging rapidly at present, and it is now known from Norway (Rueness, 1994) to the Canary Islands (Rojas-Gonzalez et al., 1994).

In the North Sea, P. harveyi has been collected in eastern England and SE Scotland (Bradwell, Essex, July 1992; and St Andrews, Fife, 17 April 1992), the Netherlands, Helgoland (Kornmann \& Sahling, 1978, as P. violacea), Norway (Rueness, 1994), Denmark (Koch, 1986, as P. fibrillosa) and Belgium (Coppejans, 1995, as P. fibrillosa). It is mostly intertidal on a wide range of substrata such as the algae Codium fragile, Sargassum muticum, Chondrus crispus, Mastocarpus stellatus and the ascidian Styela clava. It also grows on artificial surfaces such as ropes and pontoons and is particularly abundant in marinas. The first definite North Sea record dates back to 1960 (The Netherlands, spec- 
imens in L). In the Netherlands $P$. harveyi is now very common and often abundant in Oosterschelde and Grevelingen, occurring over a fairly wide range of wave exposures and substrata. It is also found in the northern Netherlands (Texel), where it appears to be the only established red invader. It occurs year-round, but is less abundant in winter (December to March) when tetrasporangia are absent.

In many localities on North Sea coasts, $P$. harveyi is now the dominant small seaweed during much of the year. It has a wide range of biological features that have given it an advantage as an immigrant. These will be discussed under the categories (1) preferred substratum, (2) habitat, (3) physiological tolerances, (4) life-history features, and (5) inferred unpalatability to grazers.

Polysiphonia harveyi grows most abundantly on algae that float and drift well, particularly Codium fragile and Sargassum muticum. It is possible that it was introduced from Japan with Codium, since it grows on this species in Japan also. Sargassum muticum, as it undergoes vigorous marginal dispersal, may carry hitch-hiking $P$. harveyi with it. Polysiphonia harveyi occupies a wide range of intertidal and subtidal habitats, both in Japan and in Europe. Its abundance on artificial substrata such as fish cages and yacht moorings facilitates its movement along the coast. It can exploit a wide range of temperatures - an isolate from Denmark grew well and reproduced at $4-22{ }^{\circ} \mathrm{C}$ (Koch, 1986). Male thalli are usually smaller than females and tetrasporophytes, sometimes reproducing when only $5 \mathrm{~mm}$ high, and are often ephemeral. Unusually, they form vegetative propagules abundantly from modified male trichoblasts; the clonal propagation of further male thalli from these may be a mechanism that compensates for the fragility of males. Finally, we have observed that in heavily Littorina-grazed pools, P. harveyi is one of the few surviving seaweeds. Members of the Rhodomelaceae are perhaps the most prolific algal synthesizers of halogenated metabolites (Fenical, 1975). Many species of Polysiphonia form a wide range of bromophenols (Fenical, 1975) which are toxic to microalgae; although grazing tests have not been carried out on Polysiphonia species, their bromophenols presumably are grazing deterrents as in the Bonnemaisoniaceae.

\section{Polysiphonia senticulosa Harvey (Rhodomelaceae, Ceramiales)}

Polysiphonia senticulosa Harvey was originally described in 1862 from Washington State, and later from Alaska, as P. pungens Hollenberg. The correct name for this species is likely to be $P$. morrowii Harvey, described from Hokkaido, Japan (Yoon, 1986), although the proposed conspecificity of $P$. morrowii and $P$. senticulos $a$ has been questioned (Kudo \& Masuda, 1988). It is apparently native to a large area of the north-eastern and north-western Pacific and is believed to have been introduced into Australia and New Zealand, possibly by shipping (Womersley, 1979; Nelson \& Maggs, 1996). This four periaxial-celled species resembles the common native European species Polysiphonia stricta (Dillwyn) Greville, but can be distinguished by a unique feature, sharply pointed vegetative tips.

It was first found in Europe on 4 May 1993 at Gorishoek, The Netherlands (collected by $\mathrm{H}$. Stegenga; specimen in $\mathrm{L}$ ), and is now common in a large part of the Oosterschelde, where it is locally abundant in the oyster ponds of Yerseke Oesterbank. It occurs there in winter and spring, from October to June, and tetrasporangial and sexual 
reproduction both take place in November to June. Its phenology in Europe closely resembles that of $P$. morrowii in Korea, which first appears in January and reproduces from the end of January to May, when it disappears (Kim et al., 1994). At present it is not known whether it was introduced independently into Australia, New Zealand and now the North Sea, but it seems likely that this species will spread further in Europe.

We have no information on which features might make $P$. senticulosa successful as an alien, but it is notable that several Polysiphonia species that have been introduced have become seriously invasive. In North Carolina, P. breviarticulata (C. Agardh) Zanardini has become a nuisance (Kapraun \& Searles, 1990), washing up in quantities on beaches, and in the Mediterranean one of the mostly rapidly spreading seaweeds is $P$. ( = Womersleyella) setacea Hollenberg, which forms dense carpets on all sublittoral surfaces (Athanasiadis, 1997).

\section{CONCLUSIONS}

North Sea aliens show a variety of distribution patterns (Fig. 1, Tables 1, 2), with geographical ranges varying from general within the North Sea to very restricted. The diversity of introduced red algae on the eastern coasts of the North Sea is much greater than that on western coasts. Only one species. Asparagopsis armata (Falkenbergia phase), is confined to British coasts, and this is restricted to the offshore islands which have milder winters than the mainland of eastern Scotland. The most likely explanation for this pattern involves (1) the initial site of introduction of the seaweeds and (2) the residual surface currents. The great majority of seaweed introductions to Europe were first observed in France, including both Atlantic and Mediterranean coasts (Boudouresque, 1994). This may be partly due to the long and diverse coastline, but is probably also related to the extensive French aquaculture industry. The diversity of alien seaweeds established in France provides a supply of propagules that drift northeast with the surface currents. Their success in The Netherlands (Table 2) has probably been promoted by the drastically changed local conditions as a result of the "Delta Hydrotechnical Works", which have also permitted the recent introduction of many native European species (Stegenga, 1998).

Comparison of the biological features of each species that may favour their success as introductions (Table 2) shows that clonal vegetative propagation is almost ubiquitous amongst North Sea red algal aliens. Only one species, Grateloupia doryphora, lacks any particular means of vegetative spread, while several of the aliens have specialized propagules or fragmentation mechanisms. Unfortunately, temperature tolerances have been investigated for less than half of the species, even though these are probably an important consideration for predictions of future spread. Finally, it is notable that many of the alien red algae in the North Sea contain anti-grazing compounds. The high bromophenol content of many members of the Ceramiales (Fenical, 1975) may contribute to their invasive potential by deterring grazing sufficiently to permit establishment of an inoculum, and sometimes the development of a bloom.

The impact of exotic red algae on native species is almost completely unknown. Several of the North Sea aliens can become extremely abundant, particularly the tetrasporophytic phases of Bonnemaisonia hamifera (Trailliella) and Asparagopsis ar- 


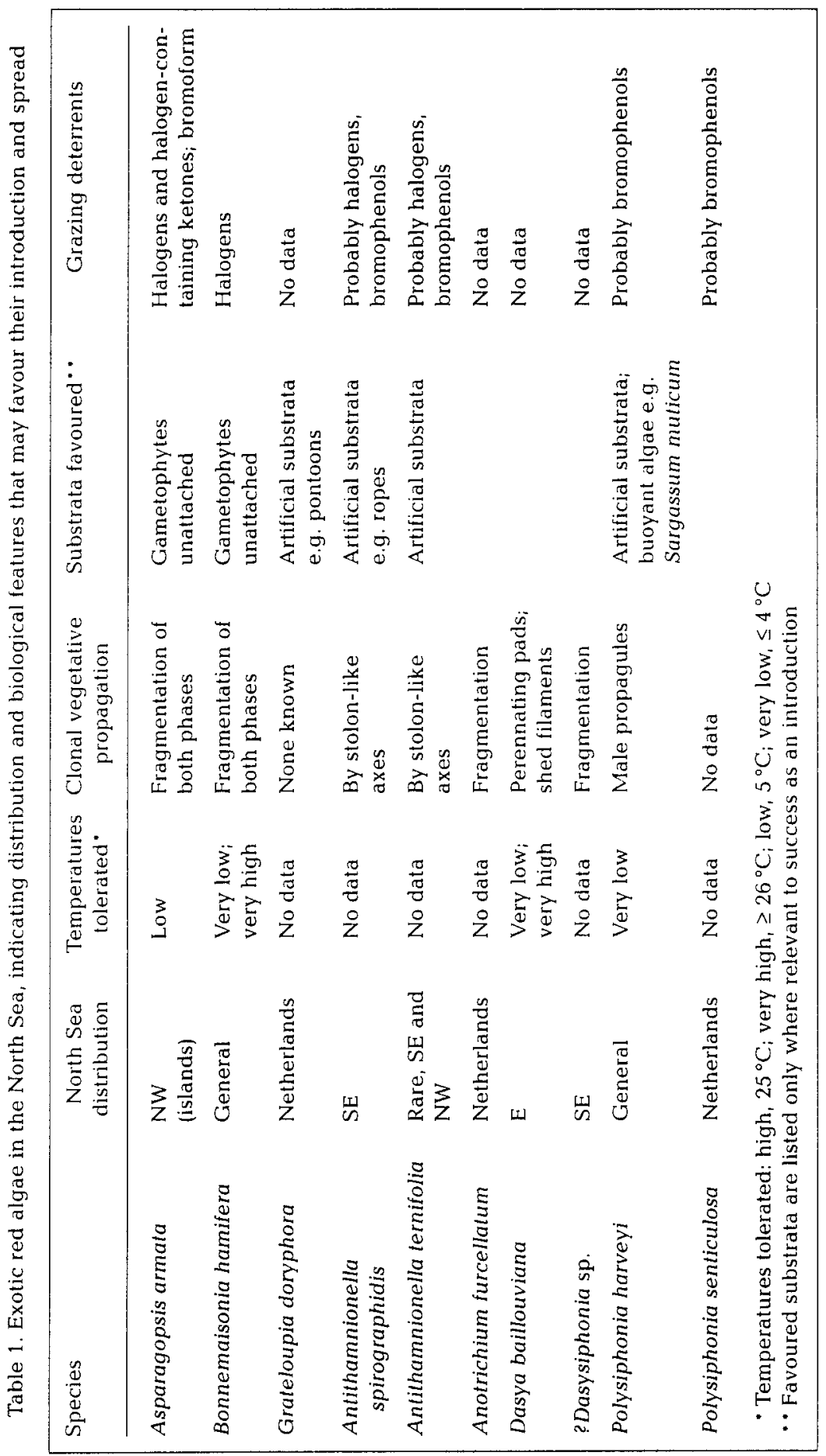


mata (Falkenbergia). The greatest abundance of Trailliella is found on sediments in impoverished communities, so there is no obvious effect on native algal species. However, when Trailliella and Falkenbergia are epiphytic, they must affect photosynthesis of the species on which they are growing, although any potential effect has never been evaluated. The majority of the aliens favour artificial substrata in man-made habitats, such as marinas and harbours, and therefore do not impact on natural communities. Overall, the effect of introduced red algae in the North Sea has been to increase species richness.

\section{LITERATURE CITED}

Athanasiadis, A., 1997. North Aegean marine algae. 4. Womersleyella setacea (Hollenberg) R. E. Norris (Rhodophyta, Ceramiales). - Bot. Mar. 40, 473-476.

Boudouresque, C.F., 1994. Les espèces introduites dans les eaux côtières d'Europe et de Méditerranée: état de la question et conséquences. In, Introduced species in European coastal waters. Ed. by C. F. Boudouresque, F. Briand \& C. Nolan. European Commission, Luxembourg, 8-27.

Boudouresque, C. F., Briand, F. \& Nolan, C., (eds) 1994. Introduced species in European coastal waters. European Commission, Luxembourg.

Breeman, A. M., Meulenhoff, E. J. S. \& Guiry, M. D., 1988. Life history regulation and phenology of the red alga Bonnemaisonia hamifera. - Helgoländer Meeresunters. 42, 535-557.

Cabioch, J., Castric-Fey, A., L'Hardy-Halos, M.-T. \& Rio, A., 1997. Grateloupia doryphora and Grateloupia filicina var luxurians (Rhodophyta, Halymeniaceae) from the coasts of Brittany (France). - Cryptogamie Algol. 18, 117-137.

Carlton, J. T. \& Geller, J. B., 1993. Ecological roulette, the global transport of nonindigenous marine organisms. - Science 261, 78-81.

Connor, D. W., Dalkin, M. J., Hill, T. O., Holt, R. H. F. \& Sanderson, W. G., 1997. Marine Nature Conservation Review: Marine biotope classification for Britain and Ireland. vol. 2. Sublittoral biotopes. Version 97.06. JNCC Report no. 230. Joint Nature Conservation Commitee, Peterborough.

Coppejans, E., 1995. Flore algologique des côtes du nord de la France et de la Belgique. Jardin Botanique National de la Belgique, Meise, $454 \mathrm{pp}$

de Jong, Y. S. D. M., van der Wurff, A. W. G., Stam, W. T. \& Olsen, J. L., 1998. Studies on Dasyaceae 3. Towards a phylogeny of the Dasyaceae (Ceramiales, Rhodophyta), based on comparative $r b c L$ gene sequences and morphology. - Eur. J. Phycol. 33, 187-201.

de Masi, F. \& Gargiulo, G. M., 1982. Grateloupia doryphora (Mont.) Howe (Rhodophyta, Cryptonemiales) en Mediterranée. - Allionia 25, 105-108.

Den Hartog, C., 1964. Ecology of Dasya pedicellata in The Netherlands. - Proc. Int. Seaweed Symp. 4, 197-201.

Dixon, P. S., 1965. Perennation, vegetative propagation and algal life histories, with special reference to Asparagopsis and other Rhodophyta. - Bot. Gothoburg. 3, 67-74.

Dixon, P. S. \& Irvine, L. M., 1970. Miscellaneous notes on algal taxonomy and nomenclature, III. Bot. Not. 123, 474-487.

Eno, N. C., Clark, R. A. \& Sanderson, W. G., (eds) 1997. Non-native marine species in British waters: a review and directory. Joint Nature Conservation Committee, Peterborough, $152 \mathrm{pp}$.

Farnham, W. F., 1980. Studies on aliens in the marine flora of southern England. In: The shore environment, vol. 2. Ecosystems. Ed. by J. H. Price, D. E. G. Irvine \& W. F. Farnham. Academic Press, London, 875-914.

Farnham, W.F., 1997. Espèces invasives sur les côtes de la Manche et de l'Atlantique. In: Dynamique d'espèces marines invasives, application à l'expansion de Caulerpa taxifolia en Méditerranée. Lavoisier Tec \& Doc, Paris, 15-35.

Feldmann-Mazoyer, G. \& Meslin, R, 1939. Note sur le Neomonospora furcellata (J. Ag.) comb. nov. et sa naturalisation dans la Manche. - Rev. Gén. Bot. 51, 193-203

Fenical, W., 1975. Halogenation in the Rhodophyta. A review. - J. Phycol. 11, 245-259. 
Hiscock, S., 1984. Marine algal communities of the St Abbs area, southeast Scotland. Nature Conservancy Council, Peterborough.

ICES, 1962. Mean monthly temperature and salinity of the surface layer of the North Sea and adjacent waters, 1905-54. ICES, Copenhagen.

Irvine, D. E. G., Guiry, M. D., Tittley, I. \& Russell, G., 1975. New and interesting marine algae from the Shetland Isles. - Br. Phycol. J. 10, 57-71.

Kapraun, D. F. \& Searles, R. B. 1990. Planktonic bloom of an introduced species of Polysiphonia (Ceramiales, Rhodophyta) along the coast of North Carolina, USA. - Hydrobiology 204/205, 269-274.

Kim, M.-S., Lee, I.K. \& Boo, S.M., 1994. Morphological studies of the red alga Polysiphonia morrowii on the Korean coast. - Korean J. Phycol. 9, 185-192.

Koch, C., 1986. Attempted hybridization between Polysiphonia fibrillosa and $P$. violacea (Bangiophyceae) from Denmark; with culture studies primarily on P. fibrillosa. - Nord. J. Bot. 6, 123-128.

Kornmann, P., 1986. Porphyra yezoensis at Helgoland - a developmental study. - Helgoländer. Meeresunters. 40, 327-342.

Kornmann, P. \& Sahling, P.-H., 1978. Meeresalgen von Helgoland. Benthische Grün-, Braun- und Rotalgen. - Helgoländer wiss. Meeresunters. 29, 1-289.

Kornmann, P. \& Sahling, P.-H., 1994. Meeresalgen von Helgoland, zweite Ergänzung - Helgoländer Meeresunters. 48, 365-406.

Kudo, T. \& Masuda, M., 1988. Taxonomic notes on Polysiphonia senticulosa Harvey and $P$. pungens Hollenberg (Ceramiales, Rhodophyta). - Jpn. J. Phycol. (Sorui) 36, 138-142.

Lee, A. J. \& Ramster, J. W., 1981. Atlas of the seas. Ministry of Agriculture, Fisheries \& Food, Lowestoft.

L'Hardy-Halos, M.-T., 1986. Observations on two species of Antithamnionella from the coast of Brittany. - Bot. Mar. 24, 37-42.

Lindstrom, S. C. \& Gabrielson, P. W., 1989. Taxonomic and distributional notes on northeast Pacific Antithamnieae (Ceramiales, Rhodophyta). - Jpn. J. Phycol. (Sorui) 37, 221-235.

Lüning, K., 1980. Control of algal life-history by daylength and temperature. In: The shore environment, vol. 2. Ecosystems. Ed. by J. H. Price, D. E. G. Irvine \& W. F. Farnham. Academic Press, London, 915-945.

Lüning, K., 1984. Temperature tolerance and biogeography of seaweeds, the marine algal flora of Helgoland (North Sea) as an example. - Helgoländer Meeresunters. 38, 305-317.

Lyle, L., 1922. Antithamnionella, a new genus of algae. - J. Bot., Lond. 60, 346-350.

Maggs, C. A. 1998. Life history variation in Dasya ocellata (Dasyaceae, Rhodophyta). - Phycologia 37, 100-105.

Maggs, C. A. \& Hommersand, M. H., 1990. Polysiphonia harveyi, a recent introduction to the British Isles? - Br. Phycol. J. 25, 92.

Maggs, C. A. \& Hommersand, M. H., 1993. Seaweeds of the British Isles. vol. 1. Rhodophyta, Part 3A Ceramiales. HMSO, London, $444 \mathrm{pp}$.

Magne, F. 1991. Sur la répartition géographique de l'Antithamnionella sarniensis (Rhodophyceae, Ceramiales). - Cryptogamie Algol. 12, 121-124.

Nelson, W. A. \& Maggs, C. A., 1996. Records of adventive marine algae in New Zealand, Antithamnionella ternifolia, Polysiphonia senticulosa (Ceramiales, Rhodophyta) and Striaria attenuata (Dictyosiphonales, Phaeophyta). - New Zealand J. Mar. Freshw. Res. 30, 449-453.

Ní Chualáin, F., 1997. The genus Asparagopsis (Bonnemaisoniaceae, Rhodophycota), comparative morphological, physiological and molecular studies. PhD thesis, National University of Ireland, Galway.

Nielsen, R. \& Kristiansen, A., 1994. Danske havalger udbredelse og danske navne. Miljø-og Energiministeriet/Skov- of Naturstyrelsen, Copenhagen, $123 \mathrm{pp}$.

Norris, J. N. \& Fenical, W., 1982. Chemical defense in tropical marine algae. In: The Atlantic Barrier Reef ecosystem at Carrie Bow Cay, Belize, I. Structure and communities. Ed. by K. Rützler \& I. G. Macintyre. Smithsonian Institution Press, Washington, 417-431.

Novaczek, I., Bird, C. J. \& McLachlan, J., 1987. Phenology and temperature tolerance of the red algae Chondria baileyana, Lomentaria baileyana, Grifithsia globifera and Dasya baillouviana in Nova Scotia. - Can. J. Bot. 65, 57-62. 
Ribera, M. A. \& Boudouresque, C. F., 1995. Introduced marine plants, with special reference to marcoalgae: mechanisms and impact. - Prog. Phycol. Res. 11, 187-268.

Richardson, J. P., 1981. Persistence and development of Dasya baillouviana (Gmelin) Montagne (Rhodophyceae, Dasyaceae) in North Carolina. - Phycologia 20, 385-391.

Rojas-Gonzalez, B., Afonso-Carrillo, J. \& Ibeas, C., 1994. New records of Rhodomelaceae (Rhodophyta) from the Canary Islands. - Bot. Mar. 37, 133-138.

Rueness, J., 1994. Polysiphonia harveyi, recent spread in Scandinavia. Comparisons and hybridization between isolates from eastern USA and Europe. Abstracts, Fifth International Phycological Congress, Qingdao, China, 26 June-2 July 1994.

Sindermann, C., Steinmetz, B. \& Hershberger, W. (eds), 1992. Introductions and transfers of aquatic species. ICES Marine Science Symposia, no. 194.

Stegenga, H., 1997. Een nieuwe Japanse invasie - vooral een systematisch probleem. - Het Zeepaard 57, 109-113.

Stegenga, H. \& Prud'homme van Reine, W. F., 1998. Changes in the seaweed flora of The Netherlands. Scarborough conference proceedings, July 13-15, 1998, University College Scarborough, in press

Stegenga, H. \& Mol, I., 1983. Flora van de Nederlandse Zeewieren. Koninklijke Nederlandse Natuurhistorische Vereniging, Amsterdam, 263 pp.

Stegenga, H. \& Otten, B. G., 1997. Recent veranderingen in de Nederlandse Zeewierflora III. Nieuwe vestigingen van soorten in de roodwiergenera Choreocolax (Choreocolacaeae), Grateloupia (Cryptonemiacede), Ceramium en Seirospora (Ceramiaceae). Gorteria 23, 69-76.

Villalard-Bohnsack, M. \& Harlin, M., 1997. The appearance of Grateloupia doryphora (Halymeniaceae, Rhodophyta) on the northeast coast of North America. - Phycologia 36, 324-328.

Wolk, C. P., 1968. Role of bromine in the formation of the refractile inclusions of the vesicle cells of the Bonnemaisoniaceae (Rhodophyta). - Planta 78, 371-378.

Womersley, H. B., S. 1979. Southern Australian species of Polysiphonia Greville (Rhodophyta). Aust. J. Bot. 27, 459-528.

Yoon, H.-Y., 1986. A taxonomic study of genus Polysiphonia (Rhodophyta) from Korea. Korean J. Phycol. 1, 3-86. 